\title{
Clostridium thermosulfurogenes sp. nov., a New Thermophile that Produces Elemental Sulphur from Thiosulphate
}

\author{
By BERNHARD SCHINK† AND J. G. ZEIKUS* \\ Department of Bacteriology, University of Wisconsin, Madison, Wisconsin 53706, U.S.A.
}

(Received 1 June 1982; revised 8 October 1982)

\begin{abstract}
A new Clostridium species is described that was isolated from a thermal, volcanic, algal-bacterial community via selective enrichment procedures with pectin as energy source. Clostridium thermosulfurogenes $\mathrm{sp}$. nov. deposits elemental sulphur on the cell surface and in the culture medium from thiosulphate transformation. This species stained Gram-negative, but electron micrographs revealed a double-layered wall without the presence of an outer membranous layer. Thin sections displayed numerous internal membranes and sulphur granules were not discernible. The organism was motile and formed distinctly swollen sporangia with terminal, white-refractile, spherical spores. The temperature range for growth was $>35^{\circ} \mathrm{C}$ and $<75{ }^{\circ} \mathrm{C}$, the $\mathrm{pH}$ range was between 4.0 and 7.5. The DNA base composition was $32.6 \pm 0.04 \mathrm{~mol} \%$ guanosine plus cytosine. Fermentable carbohydrates included pectin, starch, xylose, glucose, mannose, cellobiose, maltose, arabinose and sucrose. The doubling time on glucose or pectin was about $2 \mathrm{~h}$. The production of ethanol, $\mathrm{H}_{2} / \mathrm{CO}_{2}$, acetate and lactate accounted for a balanced fermentation of glucose, whereas methanol and isopropanol were also produced during pectin fermentation. The taxonomic relationships of $C$. thermosulfurogenes to other thermophilic clostridia and its biological role in a thermal microbial community are discussed.
\end{abstract}

\section{INTRODUCTION}

Detailed studies on the biology of thermophilic bacteria have been initiated in the last ten years in order to learn more about their function in the environment and because of their potential process applications in biotechnology (Zeikus, 1979). The most progress on understanding thermophilic anaerobe diversity in nature has been made by examination of the bacterial species common to volcanic thermal spring ecosystems (Ben-Bassat \& Zeikus, 1981; Wiegel \& Ljungdahl, 1981; Zeikus, 1979; Zeikus et al., 1979, 1980). Biotechnological research with thermophilic anaerobes has been focused primarily on methane, ethanol or acetic acid production (Ljungdahl et al., 1981; Wang et al., 1978, 1979; Zeikus, 1979, 1980; Zeikus et al., 1981).

Doemel \& Brock (1977) described the general properties of an algal-bacterial mat ecosystem in Yellowstone National Park, U.S.A., where biomass is produced and decomposed by thermophilic bacteria. Recently, the microbiology of anaerobic carbon mineralization was examined in the mat (Zeikus et al., 1980; Ben-Bassat \& Zeikus, 1981). Anaerobic bacterial species active in biomass decomposition in this ecosystem included: Thermobacteroides acetoethylicus, Thermoanaerobium brockii, Clostridium thermohydrosulfuricum and Methanobacterium thermoautotrophicum.

In the present report we describe the general morphological, cellular and metabolic characteristics of a new endospore-forming species that was repeatedly isolated from this environment by selective enrichment with pectin as the energy source for growth. The microbial properties detailed here enable distinction of this new species from $C$. thermocellum (Viljoen et al., 1926; $\mathrm{Ng}$ et al., 1977), C. thermohydrosulfuricum (Klaushofer \& Parkkinen, 1965), C. thermo-

$\dagger$ Present address: Faculty for Biology, University of Konstanz, D-7550 Konstanz, F.R.G. 
saccharolyticum (Matteuzzi et al., 1978; Hsu \& Ordal, 1970) and C. thermoaceticum (Fontaine et al., 1942).

\section{METHODS}

Chemicals. All chemicals used were reagent grade and were obtained from either Mallinckrodt (Paris, Ky., U.S.A.) or Sigma. Pectin was a gift of Sunkist Growers (Corona, Calif., U.S.A.). Agar, tryptone and yeast extract were obtained from Difco. All gases were obtained from Matheson (Joliet, Ill., U.S.A.) and were purified free of oxygen by passage over heated $\left(370^{\circ} \mathrm{C}\right)$ copper filings.

Inocula and bacterial strains. Two thermophilic strains were enriched from a $60^{\circ} \mathrm{C}$ site in the Octopus Spring algal-bacterial mat in Yellowstone National Park, Wyo., U.S.A., employing anaerobic procedures described previously (Zeikus et al., 1979, 1980). One strain was enriched in October, 1978, and a second strain in August, 1980. Both isolates had identical properties. Data presented in the results section are for type strain 4B.

Culture techniques and media. Anaerobic procedures used for cell cultivation and media preparation were described previously (Zeikus et al., 1980; Schink et al., 1981). The low phosphate buffered basal medium (LPBB medium) described by Zeikus et al. (1979) was used with a $\mathrm{N}_{2} / \mathrm{CO}_{2}(95: 5)$ gas phase. When needed, carbohydrates $(0.5 \%, w / v)$, tryptone $(1 \%, w / v)$, or yeast extract $(0.3 \%, w / v)$ were added by syringe from separately autoclaved concentrates. The medium of $\mathrm{Ng}$ et al. (1977) was used to examine cellulose fermentation, and Medium 77 (Postgate, 1963) was used to test sulphate reduction, but glucose was substituted for lactate. Routine cell maintenance and experimental analysis was performed in anaerobic culture tubes $(23 \mathrm{ml}$ volume, $18 \times 142 \mathrm{~mm})$ obtained from Bellco Glass Co. (Vineland, N.J., U.S.A.) containing $10 \mathrm{ml}$ of medium, and sealed with black rubber bungs. Prior to inoculation, culture medium was reduced by the addition of sodium sulphide $(0.05 \%, \mathrm{w} / \mathrm{v}$ final concentration). Test medium for quantification of thiosulphate reduction contained LPBB medium with $0.3 \%$ yeast extract $; 0.05 \%(\mathrm{w} / \mathrm{v}) \mathrm{FeSO}_{4} .7 \mathrm{H}_{2} \mathrm{O}, 0.02 \%(\mathrm{w} / \mathrm{v})$ sodium thioglycolate, and $0.02 \%(\mathrm{w} / \mathrm{v})$ ascorbic acid, but no sodium sulphide was added. Cultures were routinely incubated without shaking at $60{ }^{\circ} \mathrm{C}$ unless indicated in the text. For isolation of colonies in anaerobic roll tubes LPBB medium was supplemented with $0.5 \%(\mathrm{w} / \mathrm{v})$ glucose, $0.1 \%$ yeast extract and $2 \cdot 0 \%(\mathrm{w} / \mathrm{v})$ purified agar. Large quantities of cells were grown at $\mathrm{pH} 7.0 \mathrm{with}$ mixing in a MicroFerm fermenter (New Brunswick) containing 121 of LPBB medium, $0.5 \%$ glucose and $0 \cdot 1 \%$ yeast extract.

Cellular characterization. A Carl Zeiss photomicroscope was used for phase-contrast and bright-field observations including determination of cell size. Agar-coated glass slides were utilized to obtain long filaments in focus for photomicroscopy.

The methods used for preparing cells for thin sectioning and electron microscopic examination were as described by Kellenberger et al. (1958). Cells were prefixed for $2 \mathrm{~min}$ in $0.1 \%$ osmium tetroxide, washed in acetate/veronal buffer, suspended in agar, and then fixed overnight in $1 \%(\mathrm{w} / \mathrm{v})$ osmium tetroxide. All preparations were examined with a Siemens 101 electron microscope by Dr A. Ryter, Institut Pasteur, Paris, France.

DNA was isolated and purified from lysozyme-treated cells by the method of Marmur (1961). DNA base compositions were calculated according to the method of DeLey (1970) in $0.015 \mathrm{M}-\mathrm{NaCl}$ and $0.0015 \mathrm{M}$-trisodium citrate as determined in a Gilford Model 250 spectrophotometer equipped with a model 2527 thermoprogrammer. Escherichia coli DNA VIII (lot no. 57C-6830, Sigma) served as standard. DNA composition reported represents the mean of four separate determinations. The $\mathrm{G}+\mathrm{C}$ content of the $E$. coli standard was $53.9 \pm 1.0 \%$.

Cytochromes were identified in air versus dithionite-reduced difference spectra of cell extracts analysed with a Beckman model 25 scanning spectrophotometer. Cell extracts were prepared by sonicating a suspension of $1 \mathrm{~g}$ wet weight cells in $5 \mathrm{ml} 50 \mathrm{~mm}$-potassium phosphate buffer and retaining the supernatant after centrifugation at $10000 \mathrm{~g}$ for $15 \mathrm{~min}$ in a Sorvall centrifuge. Protein was determined in extracts by the Lowry method.

Crowth and metabolic characterization. Growth was determined by measuring the increase in turbidity at $660 \mathrm{~nm}$. Ab;orbance was estimated directly by insertion of the anaerobic culture tubes into a Spectronic 20 spectrophotometer (Bausch \& Lomb).

Fermentation metabolites were measured directly in liquid or gas samples removed from the culture tubes by syringe. Alcohols and acids were measured by gas chromatography, with a flame ionization detector, as described by Zeikus $e t$ al. (1979). All gases were quantified by the gas chromatography-thermal conductivity detection methods of Nelson \& Zeikus (1974). Lactate was measured spectrophotometrically by the D- or L-lactate dehydrogenase assay procedure of Bergmeyer (1965). Glucose consumption was determined by reducing-sugar analysis with dinitrophenyl salicylic acid (Miller et al., 1960).

Protein was determined by the biuret method modified for sulphur-containing solutions as described by Szarkowska \& Klingenberg (1963). This method uses a control for non-protein dependent colour formation by destruction of the colour complex via addition of potassium cyanide. Thiosulphate, sulphite, and sulphide were determined in cell-free culture fluids by the methods of Pachmayr (1960). Sulphur was determined in culture fluid by extraction with carbon disulphide and spectrophotometric analysis as described by Fliermanns \& Brock (1972). 


\section{RESULTS}

\section{Isolation and cultivation}

The organism was selectively enriched from the Octopus Spring algal-bacterial mat by serial dilution of the source inoculum in LPBB medium that contained $1.0 \%$ tryptone, $0.3 \%$ yeast extract and $0.5 \%$ pectin. The last positive tube (i.e. $10^{-3}$ dilution) displaying growth and gas production was repeatedly transferred on LPBB medium containing $0.1 \%$ yeast extract and pectin. The organism was isolated by serial dilution in agar roll tubes with LPBB, $0 \cdot 1 \%$ yeast extract and $0.5 \%$ glucose medium followed by transfer of single colonies to homologous liquid medium.

Single colonies were light yellow, $0.5-1.5 \mathrm{~mm}$ in diameter, and had a fluffy, brush-like appearance. The organism formed large colonies on agar plates incubated in an anaerobic chamber. Stock cultures maintained viability when held at room temperature or at $4{ }^{\circ} \mathrm{C}$ for two weeks. Permanent stocks were kept for more than six months by freezing anaerobic cell suspensions in $20 \%$ glycerol at $-80{ }^{\circ} \mathrm{C}$.

\section{Cellular properties}

The morphological features of $C$. thermosulfurogenes varied considerably with the age of cultures and the growth medium used (Fig. 1). Exponential phase cells grown on glucose $\mathrm{LPBB} /$ yeast extract medium were actively motile by peritrichous flagella, phase-dark, and stained Gram-negative. Stationary phase cells were more phase-light in appearance and contained dark granules. Cells existed as rods that varied considerably in length depending on the medium (i.e. as single short rods of $2 \mu \mathrm{m}$ to filamentous chains greater than $20 \mu \mathrm{m}$ ). Sporulation was never observed in glucose media but was detected in late-stationary phase cultures grown with xylose or pectin as the energy source. Sporulation was especially favoured in LPBB medium containing $0.1 \%$ yeast extract, $0.2 \%$ xylose and $1.0 \%$ MOPS buffer. Sporulating cells were on the average larger than vegetative cells and formed swollen, terminal, spherical spores (Fig. $1 b$ ). Only a few sporulating cells became distinctly phase-bright and white in old cultures; free spores were rare.

Most notably, the addition of sodium thiosulphate at $20 \mathrm{~mm}$ resulted in very turbid cultures (i.e. $A_{660}>2.0$ ) that contained a white-yellow precipitate at the end of growth. Microscopic analysis of these cultures revealed the presence of yellow elemental sulphur granules (Fig. $1 c, d$ ).

Electron microscopic analysis of $C$. thermosulfurogenes in thin section revealed some architectural features that were not typical of other clostridia (Fig. 2). Notably, internal membranes were very numerous and often appeared vesicular. The cell wall was thin and poorly discernible, but was double-layered as in most clostridia. Unlike many other Gram-negative staining bacteria no outer wall membrane layer was present. Large, electron-dense cytoplasmic granules were common in cells. All spores were spherical and swollen, but most appeared abortive because of the absence of an electron-transparent spore cortex. Thin sections of cells grown with thiosulphate did not display structures discernible as sulphur inclusions.

DNA isolated from $C$. thermosulfurogenes had a base composition of $32.6 \pm 0.04 \mathrm{~mol} \%$ guanosine plus cytosine. Difference spectra of crude cell extracts did not display absorbance bands corresponding to cytochromes. Cells lacked catalase. Cell proliferation was not detectable in the presence of: cycloserine, penicillin, streptomycin, tetracycline or chloramphenicol [each at $\left.100 \mu \mathrm{g}(\mathrm{ml} \text { culture })^{-1}\right]$; sodium azide $\left(500 \mu \mathrm{g} \mathrm{ml}^{-1}\right)$; sodium chloride $(2 \%, \mathrm{w} / \mathrm{v})$; and $\mathrm{O}_{2}(21 \%$ in the culture headspace).

\section{Growth and metabolic properties}

The optimum temperature for growth of $C$. thermosulfurogenes was near $60^{\circ} \mathrm{C}$, the maximum was below $75^{\circ} \mathrm{C}$ and the minimum above $35^{\circ} \mathrm{C}$ (Fig. 3). The growth rate and yield (i.e. turbidity) of $C$. thermosulfurogenes varied with the nutrient sources supplied (Fig. 4). The growth rate and yield was lowest on mineral medium with ammonium as nitrogen source and highest in complex medium with tryptone and yeast extract. The organism was repeatedly transferred (20 times) on glucose and mineral medium. In complex medium the cell doubling time on polymeric 

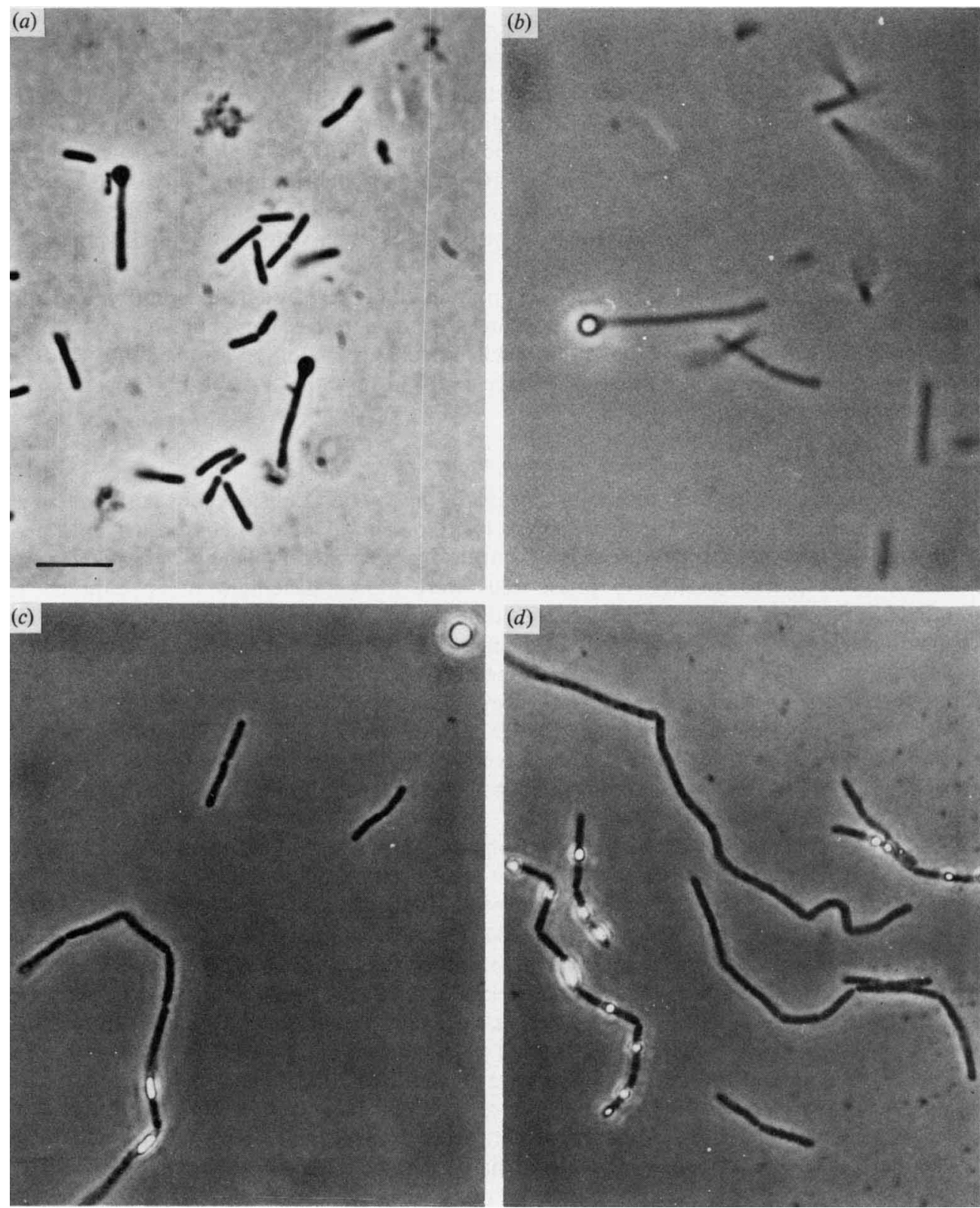

Fig. 1. Phase-contrast photomicrographs of $C$. thermosulfurogenes. $(a, b)$ Sporulating cells grown in LPBB, $0.2 \%(\mathrm{w} / \mathrm{v})$ xylose and $1.0 \%(\mathrm{w} / \mathrm{v})$ MOPS buffer medium. $(c, d)$ Sulphur-depositing cultures grown on LPBB, $0.5 \%(\mathrm{w} / \mathrm{v})$ glucose, $0.1 \%(\mathrm{w} / \mathrm{v})$ yeast extract and $20 \mathrm{~mm}-\mathrm{Na}_{2} \mathrm{~S}_{2} \mathrm{O}_{3}$. Note that phasebright sulphur accumulates in the medium and on or within the cells. The bar marker represents $5 \mu \mathrm{m}$.

pectin $(2 \cdot 1 \mathrm{~h})$ was only slightly higher than that on glucose $(1.9 \mathrm{~h})$. The optimum $\mathrm{pH}$ for growth on glucose was 5.5-6.5; growth was not observed below $4 \cdot 0$ or above 7.6.

Clostridium thermosulfurogenes fermented a wide variety of energy sources including: Larabinose, cellobiose, galactose, glucose, inositol, mannitol, maltose, melibiose, rhamnose, sucrose, trehalose, D-xylose, starch, pectin, polygalacturonic acid, amygdalin, aesculin and salicin. Cellulose, arabinogalactan, galacturonate, citrate, pyruvate, lactate, tartrate, lactose, 

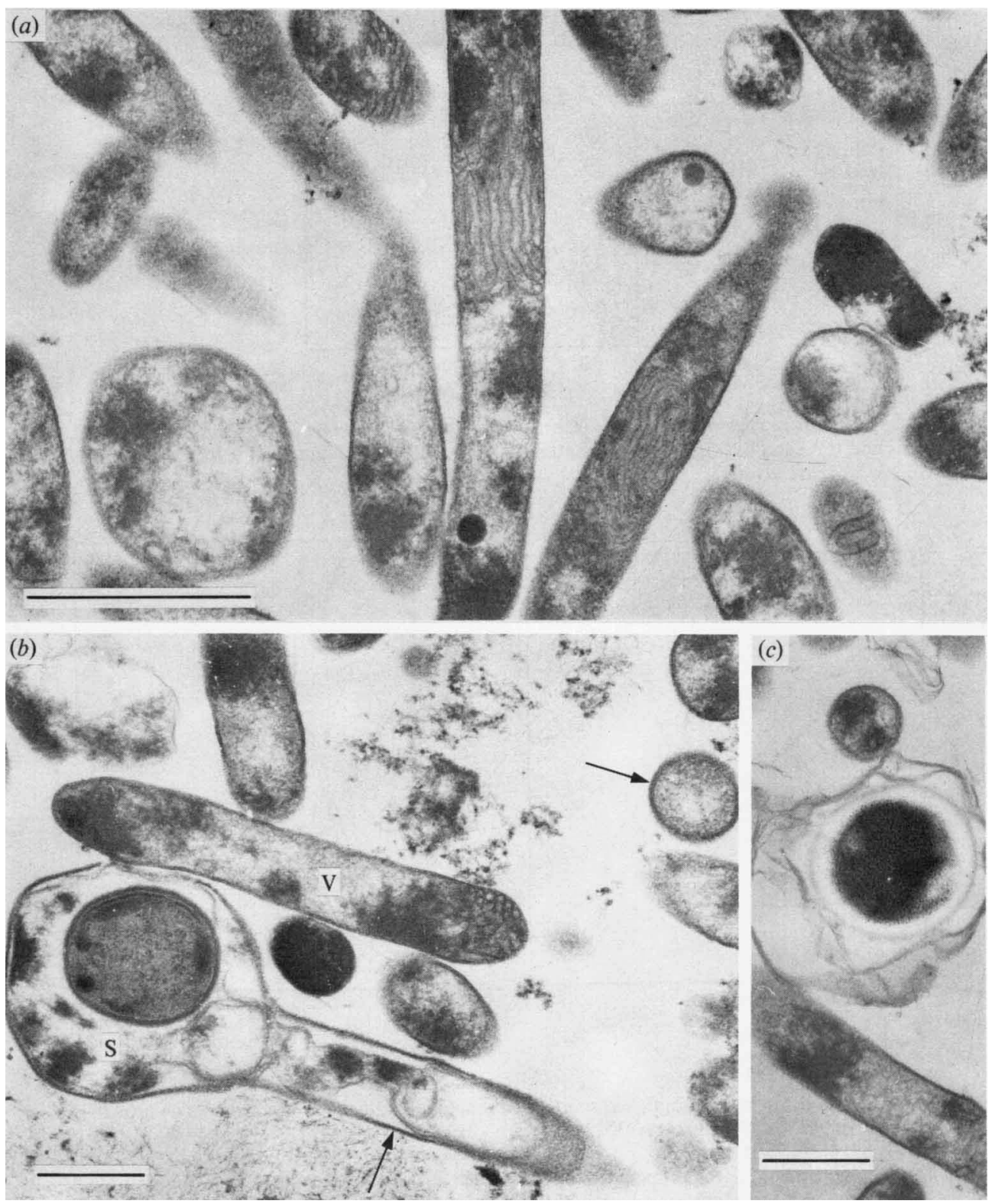

Fig. 2. Electron micrographs of thin sections of $C$. thermosulfurogenes grown on LPBB, $0 \cdot 3 \%(\mathrm{w} / \mathrm{v})$ xylose, $0.2 \%(\mathrm{w} / \mathrm{v})$ yeast extract medium. (a) Vegetative cells illustrating internal membranes. $(b)$ Sporulating cultures showing a swollen sporangium (S) and vegetative cell (V). Arrows point to 'doubletrack' appearing wall layers. (c) Free spore illustrating electron-transparent spore cortex and external coat layers. The bar marker represents $1 \mu \mathrm{m}$ in $(a)$ and $(b)$, and $0.5 \mu \mathrm{m}$ in $(c)$.

melezitose, raffinose, D-ribose, sorbitol, methanol and glycerol were not fermented. The organism liquefied gelatin, but neither produced indol, acetylmethylcarbinol or hydrogen sulphide nor reduced sulphate or nitrate.

The main products of carbohydrate fermentation by $C$. thermosulfurogenes were $\mathrm{H}_{2} / \mathrm{CO}_{2}$, ethanol, acetate and lactate (Table 1). Notably, on pectin as energy source, both methanol and 


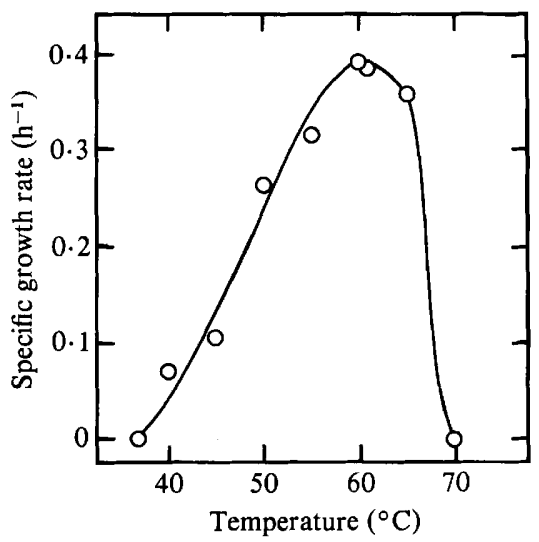

Fig. 3. Relationship between temperature and growth rate of $C$. thermosulfurogenes. Experiments were performed in anaerobic culture tubes containing $10 \mathrm{ml}$ LPBB medium with $0.5 \%(\mathrm{w} / \mathrm{v})$ glucose and $0.3 \%(w / v)$ yeast extract.

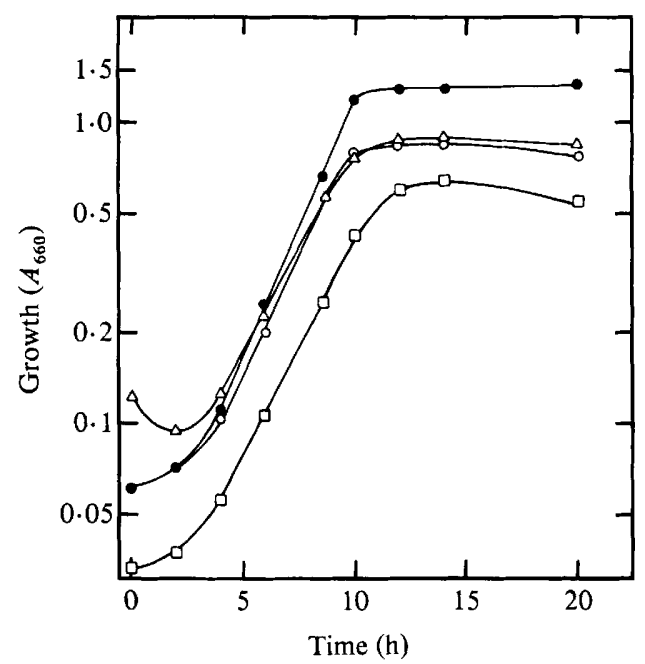

Fig. 4

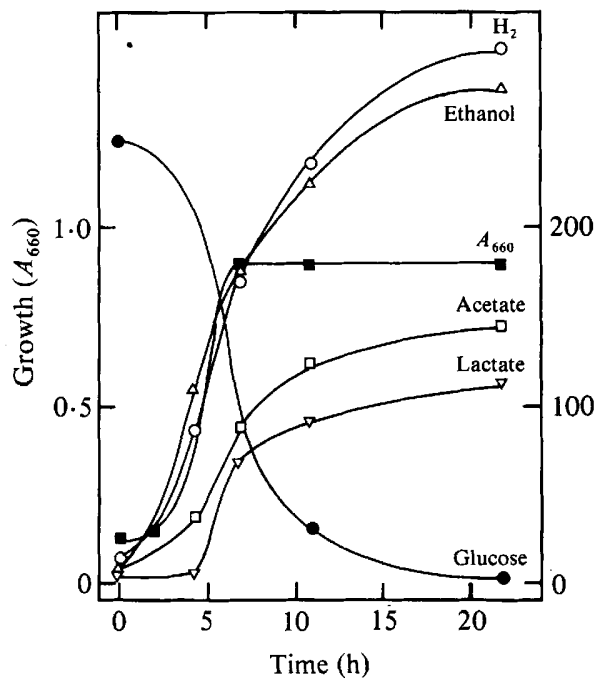

Fig. 5

Fig. 4. Relationship between nutrient source and growth of $C$. thermosulfurogenes. The growth media were: $\mathrm{LPBB}, 0.5 \%(\mathrm{w} / \mathrm{v})$ glucose, $0.3 \%(\mathrm{w} / \mathrm{v})$ years extract and $1.0 \%(\mathrm{w} / \mathrm{v})$ tryptone $(\mathrm{O}) ; \mathrm{LPBB}, 0.5 \%$ glucose and $0.3 \%$ yeast extract $(O)$; LPBB, $0.5 \%(\mathrm{w} / \mathrm{v})$ pectin and $0.3 \%$ yeast extract $(\triangle)$; and LPBB and $0.5 \%$ glucose $(\square)$. Experiments were performed in anaerobic culture tubes containing $10 \mathrm{ml}$ medium and $1 \mathrm{ml}$ inoculum grown on LPBB medium with $0.5 \%$ glucose and $0.1 \%$ yeast extract.

Fig. 5. Glucose fermentation time course of $C$. thermosulfurogenes. Experiments were performed in anaerobic culture tubes containing LPBB medium with $0.3 \%$ yeast extract and $0.5 \%$ glucose.

isopropanol were formed. Considerably more ethanol and lactate were produced on glucose than on polygalacturonate which is a more oxidized substrate. The fermentation balance calculated on glucose was 242 glucose $\rightarrow 231 \mathrm{H}_{2}+207$ ethanol +152 acetate +113 lactate $+317 \mathrm{CO}_{2}$. This accounted for a carbon recovery of $95 \%$ and an oxidation/reduction index of 0.98 .

The dependence of fermentation product formation on growth is shown in Fig. 5. All end products increased in response to growth and glucose consumption. However, both glucose consumption and end product formation continued after growth ceased. Growth appeared uncoupled by the high proton concentration $(\mathrm{pH}<4.5)$ in the medium. Growth on glucose at $\mathrm{pH}$ 
Table 1. Relationship between energy source and fermentation products formed by

C. thermosulfurogenes

All experiments were performed in anaerobic culture tubes that contained $10 \mathrm{ml}$ LPBB medium, $0.3 \%$ $(\mathrm{w} / \mathrm{v})$ yeast extract and $0.5 \%(\mathrm{w} / \mathrm{v})$ carbohydrate. Products were analysed after $24 \mathrm{~h}$ incubation at $60^{\circ} \mathrm{C}$.

\begin{tabular}{lccccccc}
\multicolumn{1}{c}{ Substrate } & Hydrogen & Methanol & Ethanol & Acetate & Lactate & Isopropanol & $\mathrm{CO}_{2}$ \\
\cline { 2 - 7 } Glucose & 231 & - & 207 & 152 & 113 & - & 317 \\
Pectin & 316 & 113 & 22 & 190 & 28 & 12 & 212 \\
Polygalacturonate & 239 & - & 37 & 265 & 23 & - & 195 \\
Xylose & 173 & - & 220 & 175 & 19 & - & ND \\
Arabinose & 168 & - & 222 & 194 & 113 & - & ND
\end{tabular}

ND, Not determined.

Table 2. Inorganic sulphur transformations of $C$. thermosulfurogenes

\begin{abstract}
All experiments were performed in anaerobic culture tubes containing $10 \mathrm{ml}$ LPBB medium, $0 \cdot 1 \%$ $(\mathrm{w} / \mathrm{v})$ yeast extract and $0.5 \%(\mathrm{w} / \mathrm{v})$ glucose, but with $\mathrm{FeSO}_{4} /$ thiosulphate/ascorbate reducing agent in lieu of $\mathrm{Na}_{2} \mathrm{~S}$. Products were analysed after $24 \mathrm{~h}$ incubation at $60^{\circ} \mathrm{C}$. Controls were uninoculated but treated the same way as other tubes.
\end{abstract}

\begin{tabular}{|c|c|c|c|c|c|c|}
\hline \multirow{3}{*}{$\begin{array}{l}\text { Additions to } \\
\text { medium (mM) }\end{array}$} & \multicolumn{2}{|c|}{ Growth } & \multirow{2}{*}{\multicolumn{4}{|c|}{ Sulphur metabolites (mM) }} \\
\hline & \multirow{2}{*}{$\begin{array}{c}\text { Turbidity } \\
\left(A_{660}\right)\end{array}$} & \multirow{2}{*}{$\begin{array}{c}\text { Protein } \\
\left(\mathrm{mg} \mathrm{ml}^{-1}\right)\end{array}$} & & & & \\
\hline & & & $\mathrm{S}_{2} \mathrm{O}_{3}{ }^{2-}$ & $\mathrm{SO}_{3}{ }^{2-}$ & $\mathrm{S}^{\mathrm{o}}$ & $\mathrm{S}^{2-}$ \\
\hline None & 0.54 & $0 \cdot 17$ & ND & 0.03 & $0 \cdot 1$ & $0 \cdot 011$ \\
\hline \multicolumn{7}{|l|}{$\mathrm{Na}_{2} \mathrm{~S}_{2} \mathrm{O}_{3}$} \\
\hline 12.5 & 0.96 & $0 \cdot 17$ & $7 \cdot 9$ & 0.28 & $3 \cdot 15$ & 0.019 \\
\hline 25 & $1 \cdot 2$ & $0 \cdot 17$ & $11 \cdot 3$ & 0.42 & $11 \cdot 85$ & 0.013 \\
\hline 25 (control) & $0 \cdot 14$ & ND & $26 \cdot 4$ & 0.43 & $0 \cdot 1$ & 0.013 \\
\hline \multicolumn{7}{|l|}{$\mathrm{Na}_{2} \mathrm{SO}_{3}$} \\
\hline 20 & $0 \cdot 36$ & 0.08 & ND & $18 \cdot 7$ & $0 \cdot 1$ & 0.022 \\
\hline
\end{tabular}

ND, Not determined.

7.0 was not inhibited by normal end-product concentrations of ethanol, acetate, lactate or by three atmospheres of $\mathrm{H}_{2} / \mathrm{CO}_{2}$.

Table 2 demonstrates the type of thiosulphate transformation shown by $C$. thermosulfurogenes. In the absence of thiosulphate, growth occurred without formation of inorganic sulphur metabolites; however, growth was not as good as in the medium with cysteine or sodium sulphide as reducing agent. Notably, the addition of increasing amounts of thiosulphate increased the culture turbidity but not the total cell protein formed. Thiosulphate was converted to elemental sulphur, but neither sulphite nor sulphide was produced. The addition of sulphite inhibited growth, but it was not converted to elemental sulphur.

\title{
DISCUSSION
}

The discovery of $C$. thermosulfurogenes extends the diversity both of known anaerobic thermophiles and of the described microbial sulphur transformation reactions. Inorganic sulphur compounds are transformed into elemental sulphur by a limited number of microbial groups. The deposition of elemental sulphur within cells or culture media appears limited to anaerobic phototrophic bacteria (Pfennig, 1967) and several aerobic sulphide-oxidizing bacterial genera (Buchanan \& Gibbons, 1974; Schedel \& Trüper, 1980). However, these kinds of bacteria utilize reduced sulphur compounds as electron donors. Clostridium thermosulfurogenes is the first fermentative chemoorganotrophic bacterium reported to form sulphur from 
thiosulphate. This transformation is especially novel because no sulphide or sulphite was detected during the conversion of thiosulphate to sulphur. The biochemical basis and physiological significance of this transformation remains a mystery. It is worth noting here that another member of the Yellowstone algal-bacterial, thermal community deposits yellow elemental sulphur: the phototroph Chloroflexus aurantiacus (Madigan \& Brock, 1975).

The presence of $C$. thermosulfurogenes appears of importance to the algal-bacterial mat ecosystem. The chemical composition of the major particulate fraction of primary production in this $55-65^{\circ} \mathrm{C}$ ecosystem (i.e. microbial cell wall layers) is not cellulose but, rather, carbohydrate and peptide-glycan polymers because the main phototrophs are Synechococcus lividus and Chloroflexus aurantiacus (Doemel \& Brock, 1977; Brock, 1978). Although other fermentative anaerobes such as $C$. thermohydrosulfuricum, $T$. acetoethylicus, $T$. brockii and $M$. thermoautotrophicum have been isolated from this environment, none of these strains can degrade pectin. There are no specific data about the pectin content of thermophilic algae, but it seems probable that Synechococcus lividus contains pectin in its sheath material as do other cyanobacterial species (Desikachary, 1959). Thus, pectin decomposition is of importance to prevent organic matter accumulation in this ecosystem where primary production and organic mineralization appear well-coupled (Doemel \& Brock, 1977). Clostridium thermosulfurogenes appeared as the prevalent pectinolytic anaerobe and was present at $\geqslant 10^{3}$ cells ( $\mathrm{ml}$ algal mat $)^{-1}$. However, this species is present in much lower numbers than total anaerobes $\left[\geqslant 10^{8} \text { cells (ml algal mat) }\right)^{-1}$; Zeikus et al., 1980]. Nonetheless, the number of pectin degraders in the algal mat is equivalent to

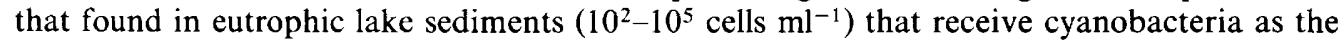
major carbon input (Schink \& Zeikus, 1982).

Clostridium thermosulfurogenes was clearly distinguishable from the other described thermophilic saccharolytic Clostridium species (Buchanan \& Gibbons, 1974). Like other Clostridium species examined by electron microscopy (Sleytr \& Glauert, 1976), it contained a double-layered wall architecture, but did not possess an outer wall membrane layer common to some Gram-negative staining anaerobes (e.g. Bacteroides or Desulfovibrio). Since it produced ethanol as the major soluble reduced end product of growth, and not butyrate or acetate, it is not similar to C. thermosaccharolyticum (Hsu \& Ordal, 1970) or C. thermoaceticum (Fontaine et al., 1942). Motility, spherical spore formation and absence of cellulose fermentation distinguishes it from C. thermocellum (McBee, 1948; $\mathrm{Ng}$ et al., 1977). It is most similar to C. thermohydrosulfuricum in substrate utilization range and fermentation end products, but it forms elemental sulphur from thiosulphate rather than $\mathrm{H}_{2} \mathrm{~S}$ (Matteuzzi et al., 1978). Other significant differences between the Octopus Spring strains of $C$. thermosulfurogenes and $C$. thermohydrosulfuricum (Zeikus et al., 1980) include: lack of growth inhibition by hydrogen, morphological features of sporogenesis, and the ability to liquefy gelatin and to ferment pectin. The ability of $C$. thermosulfurogenes to form methanol as a major fermentation product of pectin is a consequence of pectin methylesterase activity and the absence of methanol consumption by described pectinolytic bacteria (Schink \& Zeikus, 1980).

Clostridium thermosulfürogenes may have some catabolic features of biotechnological interest. As an ethanol- or lactate-producing thermophile it grows at lower $\mathrm{pH}$ values than $C$. thermocellum, T. brockii and T. acetoethylicus (Zeikus et al., 1981). Notably, the ethanol/ lactate ratio increased dramatically during growth on pentoses. This species can hydrolyse a variety of polymers including pectin, starch and gelatin. Clostridium thermosulfurogenes would appear to have very active pectinases because its growth rate on pectin is nearly equivalent to that on glucose.

\section{Clostridium thermosulfurogenes sp. nov.}

ther.mo.sul.fu.ro'ge.nes. Gr. n. thermos heat; L. n. sulfur sulphur; Gr. n. gennao to produce. thermosulfurogenes producing sulphur in heat.

Cellular characteristics. Straight rods $0.5 \times>2 \mu \mathrm{m}$. Stains Gram-negative; exponential phase cells motile by peritrichous flagellation. Forms long filaments and deposits yellow elemental sulphur on cells and in the medium when grown with thiosulphate. Swollen, white-refractile, spherical endospores formed. No outer wall membranous layer present in thin sections. Agar 
embedded colonies are fluffy, $0.5-1.5 \mathrm{~mm}$ in diameter, and not pigmented. DNA base composition of $32.6( \pm 0.04) \mathrm{mol} \% \mathrm{G}+\mathrm{C}$. Cytochromes undetectable; catalase negative.

Growth characteristics. Optimum temperature for growth is $\geqslant 60^{\circ} \mathrm{C}$, maximum $75^{\circ} \mathrm{C}$, minimum $35^{\circ} \mathrm{C}$. $\mathrm{pH}$ range for growth: optimum 5.5-6.5, minimum $>4 \cdot 0$, maximum $<7 \cdot 6$. Obligate thermophile and anaerobe. Complete growth inhibition by penicillin, streptomycin, cycloserine, tetracycline, chloramphenicol (each at $\left.100 \mu \mathrm{g} \mathrm{ml}^{-1}\right)$, sodium azide $\left(500 \mu \mathrm{g} \mathrm{ml}^{-1}\right)$ or $\mathrm{O}_{2}\left(0.203 \times 10^{5} \mathrm{~Pa}\right)$.

Metabolic characteristics. Chemoorganotroph. Utilizes a wide variety of carbohydrates as energy sources including pectin, arabinose, cellobiose, polygalacturonate, rhamnose, amygdalin, salicin, inositol, mannitol, xylose, galactose, glucose, mannose, maltose, starch, melibiose, sucrose, trehalose or aesculin. No growth on $\mathrm{H}_{2} / \mathrm{CO}_{2}$, lactose, cellulose, tartrate, lactate, pyruvate, methanol or glycerol. Fermentation products of glucose are ethanol, $\mathrm{H}_{2}, \mathrm{CO}_{2}$, lactate and acetate. Methanol and isopropanol formed on pectin. Sulphate, sulphite and nitrate not reduced.

Habitat. Algal-bacterial mat ecosystems associated with thermal, volcanic springs. Type strain 4B. This strain was isolated from Octopus Spring, Yellowstone National Park, U.S.A. The strain has been deposited in both the Deutsche Sammlung von Mikroorganismen (DSM 2229) and the American Type Culture Collection, Rockville, Md., U.S.A. (ATCC 33743).

This research was supported by the College of Agricultural and Life Sciences, University of Wisconsin; and in part, by grant No. 12-140 from the USDA Forest Service, Forest Products Laboratory. The authors want to thank Tom J. Phelps for his help in sampling in Yellowstone National Park, and Gina Cuccia for technical assistance. B.S. thanks the Deutsche Forschungsgemeinschaft for an educational stay at the University of Wisconsin.

\section{REFERENCES}

Ben-Bassat, A. \& Zeikus, J. G. (1981). Thermobacteroides acetoethylicus. gen. nov. sp. nov., a new chemoorganotrophic, anaerobic bacterium. Archives of Microbiology 128, 365-373.

BergmeYer, H. U. (1965). Methods of Enzymatic Analysis. Weinheim. F.R.G.: Verlag Chemie.

Brock, T. D. (1978). Thermophilic Microorganisms and Life at High Temperatures. New York: Springer Verlag.

Buchanan, R. E. \& Gibbons, N. E. (1974). Bergey's Manual of Determinative Bacteriology, 8th edn. Baltimore: Williams \& Wilkins

DELEY, J. (1970). Reexamination of the association between melting point, bugyant density and the chemical base composition of deoxyribonucleic acid. Journal of Bacteriology 101, 738-754.

Desikachary, T. V. (1959). Cyanophyta. New Delhi: Indian Council of Agricultural Research.

Doemel, W. N. \& Brock, T. D. (1977). Structure, growth and decomposition of laminated algalbacterial mats in alkaline hot springs. Applied and Encironmental Microbiology 34, 433-452.

Fliermanns, C. B. \& Brock, T. D. (1972). Assay of elemental sulphur in soil. Soil Science 115, 120-122.

Fontaine, F. E., Peterson, W. H., McCoy, E., JoHnson, M. J. \& RitTer, G. J. (1942). A new type of glucose fermentation of Clostridium thermoaceticum sp. nov. Journal of Bacteriology 43, 701-705.

Hsu, E. T. \& Ordal, Z. J. (1970). Comparative metabolism of vegetative and sporulating cultures of Clostridium thermosaccharolyticum. Journal of Bacteriology 102, 364-376.

Kellenberger, E., Ryter, A. \& Sechaud, R. (1958).
Electron microscopic study of DNA containing plasmids II. Vegetative and mature phage DNA as compared with normal bacterial nucleoids in different physiological states. Journal of Biophysical and Biochemical Cytology 4, 671-676.

Klaushofer, H. \& Parkkinen, E. (1965). Zur Frage der Bedeutung aerober und anaerober thermophiler Sporenbildner als Infektionsursache in Rübenzuckerfabriken. I. Clostridium thermohydrosulfuricum, eine neue Art eines saccharolytischen Clostridiums. Zeitschrift für Zuckerindustrie 15, 445-449.

Luungdahl, L. G., Bryant, F., Curreira, L., Saiki, T. \& WIEGEL, J. (1981). Some aspects of thermophilic bacteria. In Trends in the Biology of Fermentations for Fuels and Chemicals, pp. 397-420. Edited by A. Hollaender. New York: Plenum Press.

Madigan, M. T. \& Brock, T. D. (1975). Photosynthetic sulphide oxidation by Chloroflexus aurantiacus, a filamentous, photosynthetic, gliding bacterium. Journal of Bacteriology 122, 782-784.

MARMUR, J. (1961). A procedure for the isolation of deoxyribonucleic acid from microorganisms. Journal of Molecular Biology 3, 208-218.

Matteuzzi, D., Hollaus, F. \& Biavati, B. (1978). Proposal of neotype for Clostridium thermohydrosulfuricum and the merging of Clostridium tartarivorum with Clostridium thermosaccharolyticum. International Journal of Systematic Bacteriology 28, 528531 .

MCBEE, R. H. (1948). The culture and physiology of a thermophilic cellulose-fermenting bacterium. Journal of Bacteriology 56, 653-664.

Miller, G. L., Blum, R., Glenmore, W. E. \& 
Burton, A. L. (1960). Measurement of carboxymethylcellulase activity. Analytical Biochemistry 1, 127-132.

Nelson, D. R. \& Zeikus, J. G. (1974). Rapid method for the radioisotopic analysis of gaseous end products of anaerobic metabolism. Applied Microbiology 28, 258-261.

NG, T. K., Weimer, P. \& Zeikus, J. G. (1977). Cellulolytic and physiological properties of Clostridium thermocellum. Archites of Microbiology 114, 1-7.

PACHMAYR, I. (1960). Vorkommen und Bestimmung von Schwefelcerbindungen in Mineralwasser. Ph.D. thesis, Munich University.

Pfennig, N. (1967). Photosynthetic bacteria. Annual Review of Microbiology 21, 285-324.

Postgate, J. R. (1963). Versatile medium for the enumeration of sulphate-reducing bacteria. Applied Microbiology 11, 265-267.

SCHEDEL, M. \& TRÜPER, H. G. (1980). Anaerobic oxidation of thiosulphate and elemental sulphur in Thiobacillus denitrificans. Archives of Microbiology 124, 205-210.

Schink, B. \& ZEIKus, J. G. (1980). Microbial methanol formation: a major end product of pectin metabolism. Current Microbiology 4, 387-389.

Schink, B. \& Zeikus, J. G. (1982). Microbial ecology of pectin metabolism in anoxic lake sediments. Journal of General Microbiology 128, 393-404.

SChINK, B., WARD, J. C. \& ZeIKUS, J. G. (1981). Microbiology of wetwood: role of anaerobic bacterial populations in living trees. Journal of General Microbiology 123, 313-322.

Sleytr, U. B. \& Glauert, A. M. (1976). Ultrastructure of the cell walls of two closely related Clostridia that possess different regular arrays of surface subunits. Journal of Bacteriology 126, 863882.

Szarkowska, L. \& KLingenberG, K. (1963). On the role of ubiquinone in mitochondria. Spectro- photometric and chemical measurements of its redox reactions. Biochemische Zeitschrift 338, 674-697.

Vilioen, J. A., Fred, E. B. \& Peterson, W. H. (1926). The fermentation of cellulose by thermophilic bacteria. Journal of Agricultural Science 16, 1-17.

WANG, D. I. C., Fleischer, R. J. \& WANG, G. Y. (1979). Novel synthesis of acetic acid by Clostridium thermoaceticum. AICHE Symposium Series No. 182 74, 105-111.

WANG, D. I. C., Biocic, F., FANG, H. Y. \& WANG, G. Y. (1979). Direct microbiological conversion of cellulosic biomass to ethanol. Proceedings of the 3rd Annual Biomass Energy Systems Conference, National Technical Information Service, Springfield, Virginia, pp. 61-67.

WIEgel, J. \& LuUngDahl, L. G. (1981). Thermoaerobacter ethanolicus gen. nov. sp. nov., a new extreme thermophilic anaerobic bacterium. Archives of Microbiology 128, 343-351.

ZEIKus, J. G. (1979). Thermophilic bacteria: ecology, physiology and technology. Enzyme and Microbial Technology 1, 243-252.

ZeIKus, J. G. (1980). Chemical and fuel production by anaerobic bacteria. Annual Review of Microbiology 34, 423-464.

Zeikus, J. G., HegGe, P. W. \& Anderson, M. A. (1979). Thermoanaerobium brockii gen. nov. and sp. nov, a new chemoorganotrophic, caldoactive, anaerobic bacterium. Archives of Microbiology 122, 41-48.

Zeikus, J. G., Ben-Bassat, A. \& Hegge, P. W. (1980). Microbiology of methanogenesis in thermal, volcanic environments. Journal of Bacteriology 143, 432-440.

Zeikus, J. G., Ben-Bassat, A., NG, T. K., Lamed, R. J. (1981). Thermophilic ethanol fermentations. In Trends in the Biology of Fermentations for Fuels and Chemicals, pp. 397-420. Edited by A. Hollaender. New York: Plenum Press. 